\title{
Symbiosis between methane-oxidizing bacteria and a deep-sea carnivorous cladorhizid sponge
}

\author{
Jean Vacelet ${ }^{1, *}$, Aline Fiala-Médioni ${ }^{2}$, C. R. Fisher ${ }^{3}$, Nicole Boury-Esnault ${ }^{1}$ \\ 'Centre d'Océanologie de Marseille, Université de la Méditerranée - UMR CNRS no. 6540, Station Marine d'Endoume, \\ F-13007 Marseille, France \\ ${ }^{2}$ Observatoire Océanologique, Laboratoire Arago, F-66650 Banyuls-sur-Mer, France \\ ${ }^{3}$ Department of Biology, Pennsylvania State University, University Park, Pennsylvania 16802, USA
}

\begin{abstract}
Dense bush-like clumps of several hundred individuals of a new species of Cladorhiza (Demospongiae, Poecilosclerida) were observed near methane sources in mud volcanoes, 4718 to $4943 \mathrm{~m}$ deep in the Barbados Trench. The sponge tissue contains 2 main morphological types of extracellular symbiotic bacteria: small rod-shaped cells and larger coccoid cells with stacked membranes. Stable carbon isotope values, the presence of methanol dehydrogenase and ultrastructural observations all indicate that at least some of the symbionts are methanotrophic. Ultrastructural evidence of intracellular digestion of the symbionts and the stable $C$ and $N$ values suggest that the sponge obtains a significant portion of its nutrition from the symbionts. Ultrastructure of the sponge embryo suggests direct transmission through generations in brooded embryos. The sponge also maintains a carnivorous feedıng habit on tiny swimming prey, as do other cladorhuzids.
\end{abstract}

KEY WORDS: Methanotrophy Porifera - Deep-sea S Symbiosis C Cold-seep communities

\section{INTRODUCTION}

Associations between several phyla of marine invertebrates and chemoautotrophic sulfur-oxidizing and/or methanotrophic bacteria are frequently found in marine communities surrounding hydrothermal vents, cold seeps, and other reducing environments (Childress et al. 1986, Fiala-Médioni \& Felbeck 1990. Cavanaugh 1993, Nelson \& Fisher 1995). These associations often dominate deep-sea communities depending on chemosynthesis, locally resulting in a high density of invertebrates. These oases of life have a faunal biomass several orders of magnitude higher than that of the surrounding deep sea (Grassle 1986, Tunnicliffe 1991).

Sponges had not previously been documented among the dense assemblages of invertebrates thriving in hydrothermal vent effluents (Tunnicliffe 1991),

\footnotetext{
-E-mail: jvacelet@com.unı-mrs.fr

although they are sometimes abundant on extinct chimneys (Boury-Esnault \& De Vos 1988) or in vent peripheral areas. The lack of sponges in most chemosynthetic communities is rather surprising as they are probably the marine invertebrates in which symbiosis with the widest variety of microsymbionts, algae and heterotrophic bacteria occurs (Vacelet \& Donadey 1977, Wilkinson 1987, 1992). All sponge species examined to date are associated with microsymbionts, and in the case of 'bacteriosponges' the symbionts may constitute more than one-third of the total tissue volume (Vacelet 1975, Reiswig 1981). However, until very recently, associations with methanotrophic bacteria were not described in the Porifera.

The discrete participation of sponges in deep-sea ecosystems directly depending on chemosynthesis may be due to the absence of adaptations of these sedentary organisms to life in such harsh, rapidly changing environments (Grassle 1986). However, it is also possible that sponges are more abundant in these assemblages than previously thought, given the poor knowledge of the distribution, biology and cytology of 
deep-sea sponges. Recently, associations between demosponges and methanotrophic bacteria occurring near methane sources have been reported in the deep sea (Harrison et al. 1994, Vacelet et al. 1995) and in the deep lake Baikal, Irkutsh (Efremova et al. 1995). The association apparently results in an unusual abundance of sponges near the hydrocarbon sources.

Here we describe one of these associations, which was first reported in 1995 (Vacelet \& Boury-Esnault 1995) The host, a carnivorous sponge without an aquiferous system, is abundant around deep-sea mud volcanoes near the Barbados accretionary prism. It harbors 2, possibly 3, morphological types of bacteria. The tissue $\delta^{13} \mathrm{C}$ and $\delta^{1.5} \mathrm{~N}$ values, the presence of a key enzyme of methanotrophy in the sponge tissue, the habitus and distribution of the animal, and the ultrastructure of some symbionts all support the thesis that at least some of the symbionts are methanotrophic. Ultrastructural evidence is presented for intracellular phagocytic digestion of the bacteria by the sponge and for direct transmission of the bacteria through generations.

\section{MATERIALS AND METHODS}

Sampling. Specimens (Fig 1) were collected from mud volcano fields in the Barbados Trench during the 'Baresnaut' (1987) and 'Manon' (1992) cruises (Henry et al. 1990, Le Pichon et al. 1990, Olu et al. in press). Field observations and collections were made by means of the submersible 'Nautile' (IFREMER) on the diatreme Atalante during the dives Manon MAO1

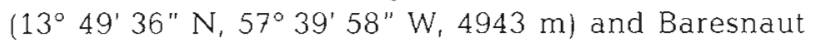
PL $94 / 3\left(13^{\circ} 49^{\prime} \mathrm{N}, 57^{\circ} 38^{\prime} \mathrm{W}, 4935 \mathrm{~m}\right)$, and on the diapir Mount Manon during the dive Manon MA06 $\left(13^{\circ} 46^{\prime} 74^{\prime \prime} \mathrm{N}, 57^{\circ} 32^{\prime} 51^{\prime \prime} \mathrm{W}, 4718 \mathrm{~m}\right)$.

Immediately after recovery, small samples of the specimens from the Manon cruise were either preserved for cytology or frozen. The remaining speci-

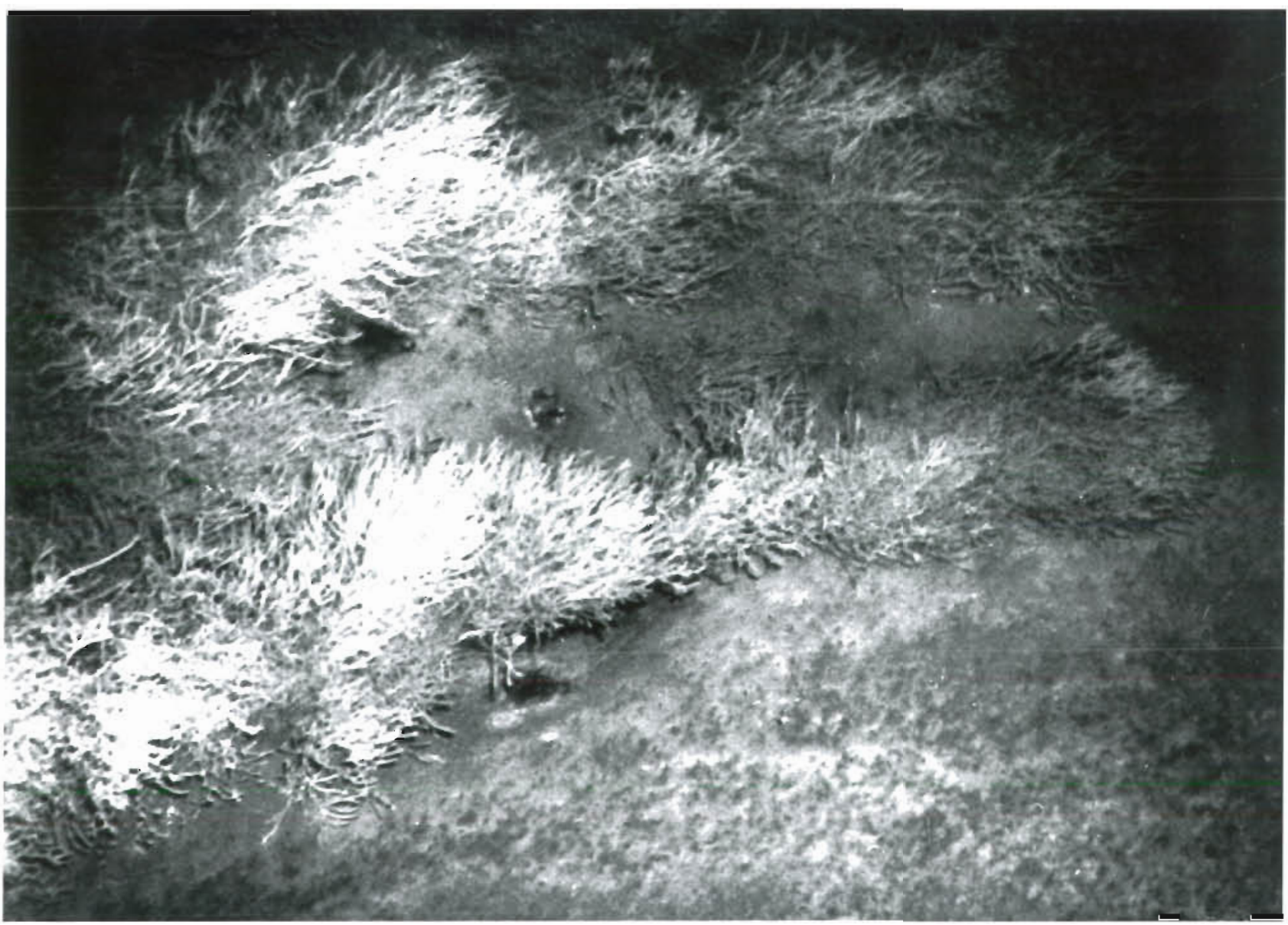

Fig. 1. Cladorhiza sp. Large bush of cladorhizid sponges, approximately $40 \mathrm{~cm}$ high, observed from the submersible 'Nautile' at $4943 \mathrm{~m}$ in the mud volcano Atalante in the Barbados Trench. The bushes were most abundant and larger around the periphery of the mud-volcano eye where the largest amounts of methane were detected (OIFREMER) 
mens, approximately 100 individuals, were preserved in alcohol. The sponge is a new species of Cladorhiza (Demospongiae, Cladorhizidae) which will be described in a forthcoming paper. Reference specimens have been deposited in the Muséum National d'Histoire Naturelle in Paris (no. MNHN D JV 57)

Cytology. The specimens were fixed in $3 \%$ glutaraldehyde in $0.4 \mathrm{M}$ cacodylate buffer ( $\mathrm{pH}$ 7.4) and postfixed in $1 \%$ osmium tetroxide in the same buffer. They were dehydrated through an alcohol series and embedded in Araldite. Thin sections were cut after local desilicification in $5 \%$ hydrofluoric acid applied on the free surface of the trimmed block (Borojevic \& Lévi 1967). Semi-thin sections were stained with toluidine blue. Thin sections were contrasted with uranyl acetate and lead citrate, and observed under a Hitachi Hu 600 or Zeiss EM 912 transmission electron microscope.

Tissue analyses. Key enzymes of methylotrophic and chemoautotrophic sulfur-oxidizing bacteria were tested as follows. RUBISCO (EC 4.1.1.39) activity was assayed by the method of Wishnick \& Lane (1971) as modified by Felbeck (1981). Methanol dehydrogenase was assayed by the method of Anthony \& Zathman (1965). ATP sulfurylase (EC 2.7.7.4) and ATP reductase (EC 1.8.99.2) were determined spectrophotometrically as described in Felbeck (1981).

Tissue stable carbon and nitrogen isotope analyses were conducted on freeze-dried and acidified samples using standard methods with combustion techniques by J. Boulègue and A. Mariotti (Université P. et M. Curie, Paris, Laboratoire de Géochimie et Chimie isotopique). The analyses were accomplished on a Finningan Delta $E$ mass spectrophotometer. Carbon is reported relative to $\mathrm{PDB}$ (PeeDee Belemnite) and nitrogen to atmospheric molecular nitrogen.

\section{RESULTS}

\section{Cytology}

The sponge (Fig. 1) is 4 to $40 \mathrm{~cm}$ high and has the hydroid-like appearance typical of the genus, erect and branching with a cylindrical body 1 to $1.25 \mathrm{~mm}$ in diameter from which arise numerous lateral branches 2 to $3 \mathrm{~mm}$ long and 0.12 to $0.25 \mathrm{~mm}$ in diameter Although it is devoid of an aquiferous system, as is usual in cladorhizids (Sars 1872, Lundbeck 1905), no part of the sponge tissue is distant from the external medium due to the thinness of both body and lateral branches

The tissue of the sponge body was found to be composed of various types of rounded or stellate cells, whose ultrastructural preservation was irregular, orga- nized around a dense central axis of spicules. It contained ovoid embryos $250 \mu \mathrm{m}$ in maximum diameter. The tissue contained 2, possibly 3 , morphological types of bacteria, distinctly different in size and ultrastructure. Both common types were present in several different extra- or intracellular locations throughout the sponge. The lateral appendages of the sponge, which were not examined by electron microscopy, appeared under light microscopy to have the same organization as the body. No gradient in the structure and distribution of bacteria and bacteriocytes in the diverse zones of the sponge body was discernible. No difference was observed between the samples from the 2 locations (diatreme Atalante and Mount Manon).

Extracellular symbionts were found at low density in the matrix of the sponge body among collagen fibrils (Fig. 2A, B). Their distribution was patchy, although large clusters of symbionts were occasionally seen. A rough estimate of the volume of the various tissue components made from TEM micrographs indicated that the extracellular bacteria never exceed $12 \%$ of the total tissue volume in the areas examined. When extracellular, the symbionts were intact with no signs of degradation, and division stages were observed (Fig. 2B).

The symbionts were also abundant intracellularly in the sponge mesohyl (Fig. 2C, D). Symbionts were observed in all cell types, including the sclerocytes which secrete the siliceous spicules. The symbionts occurred either singly or loosely grouped in vacuoles of diverse size (Fig. 2C, D), or crowded in large, round vacuoles (Fig. 3). The different symbiont types were generally found in separate inclusions or vacuoles, although they were occasionally seen together. Many of the intracellular symbionts appeared to be in various stages in degradation, especially those crowded in the large vacuoles, suggesting lysosomal digestion by the host cell. Because of their distinct ultrastructure, the larger bacteria with stacked lamellae were easily recognizable in various stages of degradation in these vacuoles (Fig. 3). The degrading bacteria had a more electron-opaque cytoplasm, more closely packed stacked lamellae and an irregular shape. In the most. advanced stages, the bacteria were reduced to myelinlike figures or simply the cell wall (Fig. 3A). Degradation of the smaller symbionts was more difficult to follow due to their lack of visually distinct ultrastructural features (such as stacked membranes and electronlucent vacuoles), but was occasionally apparent (Fig. 3A). The symbionts in a given vacuole of a bacteriocyte were usually of consistent appearance; however, vacuoles with symbionts in different stages of digestion were often present in the same cell (Fig. 3).

The symbionts were also observed within flattened cells which formed a thin layer at the surface of 


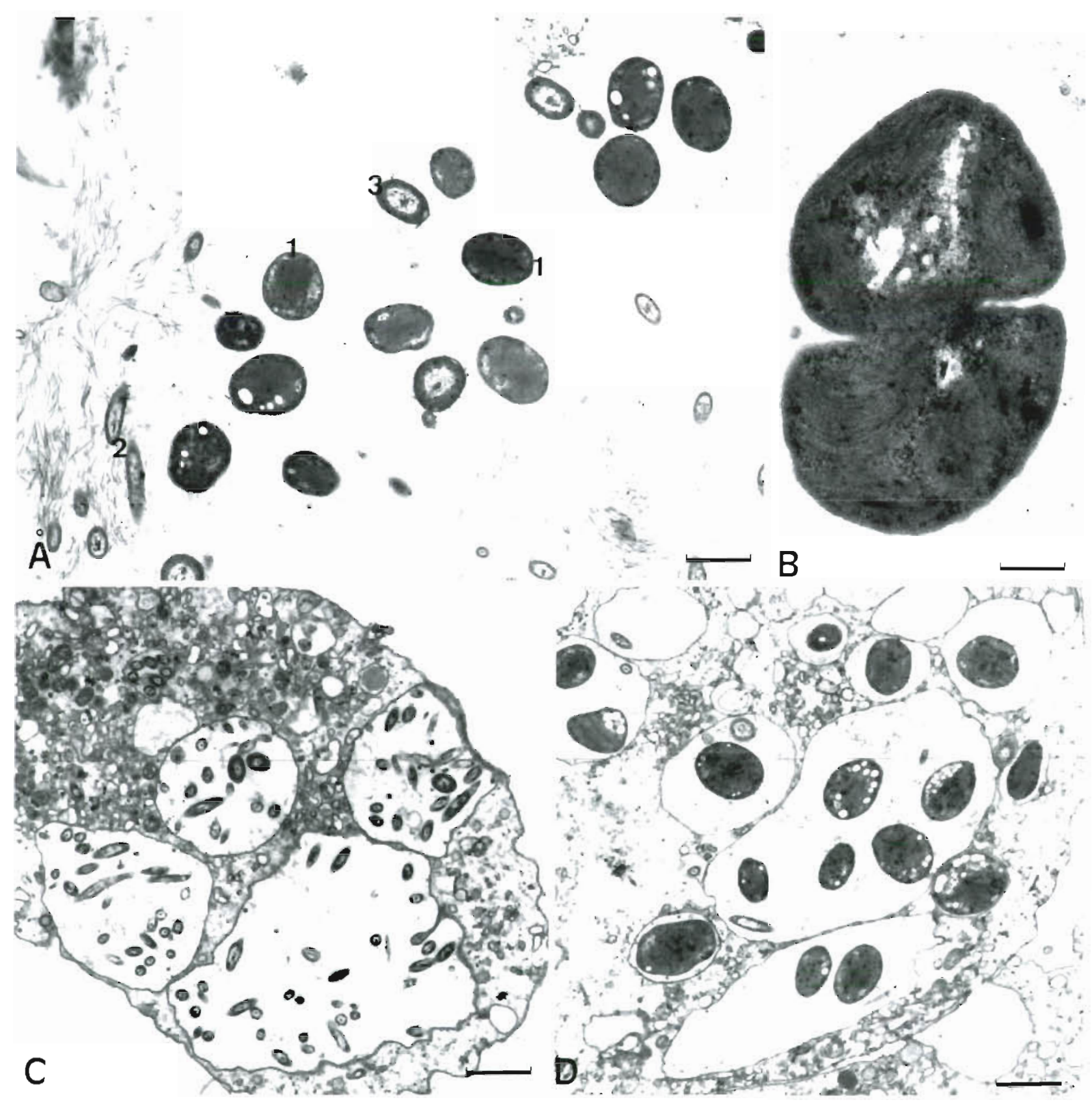

Fig. 2. Extracellular and intracellular microsymbionts in Cladorhizd sp. tissues. (A) Two ultrastructural types of bacteria are present in the intercellular space: (1) Type I methanotroph with stacked lamellae and (2) smaller rod-shaped cells. A third morphological type (3) was observed very rarely. Scale bar $=1.2 \mu \mathrm{m}$. (B) Division stage of an extracellular microsymbiont (Type I methanotroph). Scale bar $=0.29 \mu \mathrm{m}$. (C) Vacuoles containing a single type of microsymbiont (small rod-shaped bacteria). Scale bar $=1.28 \mu \mathrm{m}$. (D) Vacuoles containing both types of microsymbionts, although bacteria with stacked lamellae are dominant. Scale bar $=1.28 \mu \mathrm{m}$

embryos (Fig. 4). Only a single developmental stage of the embryo was observed and it is not known whether these cells are embryonic cells or follicle cells from the mother sponge surrounding the embryos. The first interpretation is more likely as the flattened-cell layer is located inside a dense collagen layer surrounding the embryo. In the embryo cells, the symbionts were always contained singly within a vacuole. No obviously degrading or dividing symbionts were observed in this location. Symbionts were absent from the large internal cells of the embryo, which contained numerous yolk and lipid inclusions.

Two, possibly 3, ultrastructural types of symbiotic bacteria with Gram-negative-type cell walls were 

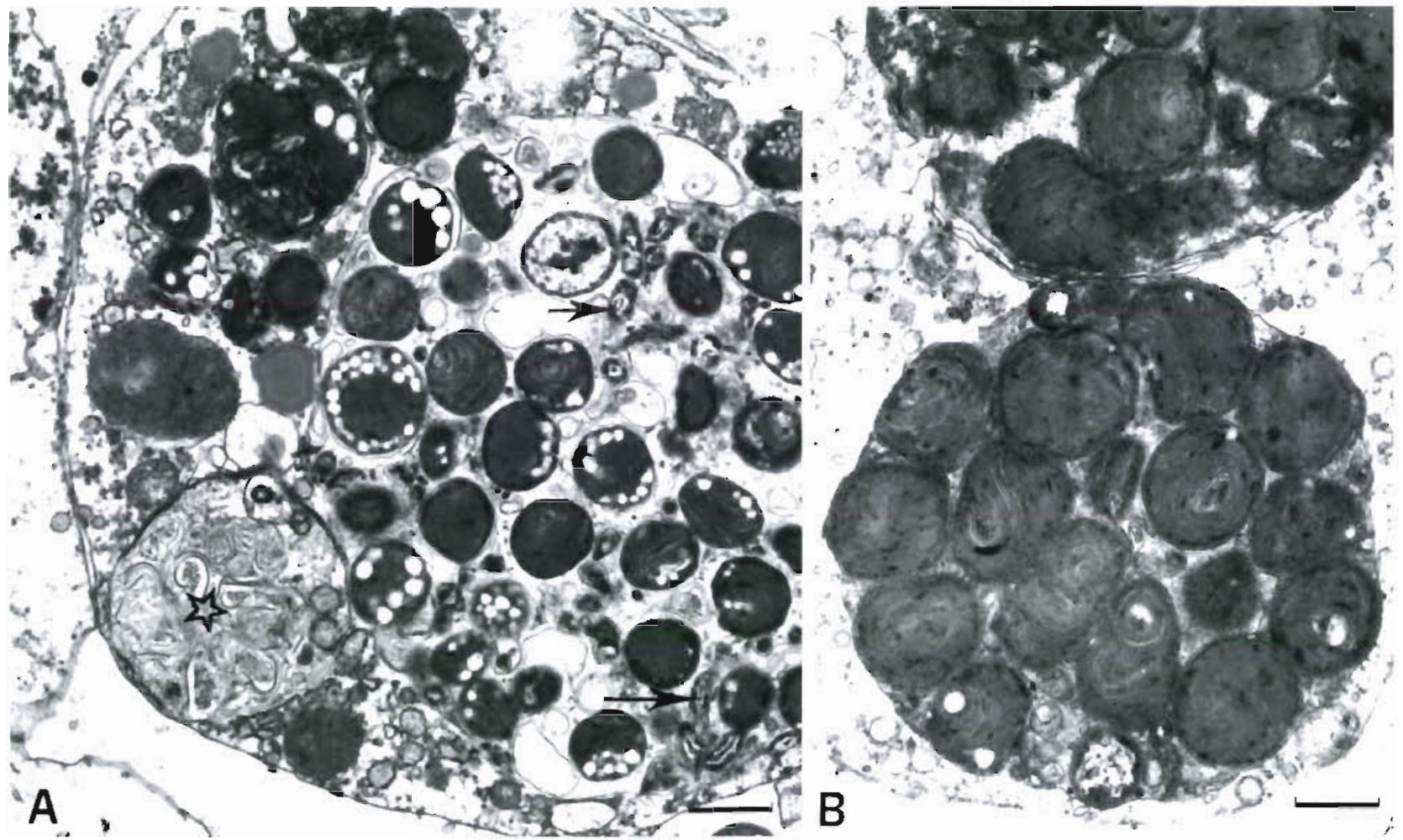

Fig. 3. Intracellular degradation of microsymbionts of Cladorhiza sp. (A) A sponge cell containing vacuoles with Type I methanotrophs in various stages of degradation. Small rod-shaped bacteria are less clearly recognizable (arrows). Note the large number of electron-lucent granules in several bacteria, possibly poly-hydroxy-butarate, and the inclusion with myelin-like figures (A), presumably a lysosomal residual body. Scale bar $=1 \mu \mathrm{m}$. (B) Apparently synchronous degradation of Type I methanotrophs in 2 vacuoles of a sponge cell. Scale bar $=0.7 \mu \mathrm{m}$

present in the sponges (Fig. 5): (1) The most abundant were coccoid cells, 1 to $1.7 \mu m$ in diameter (Fig. 5A, C). They contained stacks of flattened vesicles, approximately $20 \mathrm{~nm}$ in width, arranged in parallel in the center of the cell. The cells also contained small dense granules and a variable number of spherical or irregular vacuoles in their peripheral cytoplasm. Electron-lucent droplets, 0.1 to $0.15 \mu \mathrm{m}$ in diameter, were often visible in intracellular symbionts, but rare in extracellular symbionts (Fig. 3A). This morphology is typical of Type I methanotrophic bacteria (Davies \& Whittenbury 1970, Higgins et al. 1981), and reminiscent of the methanotrophic symbionts seen in several species of deep-sea mytilids (Cavanaugh 1993, Fisher 1993). (2) The second type were smaller, oval to rod-shaped cells, 0.25 to $0.85 \mu \mathrm{m}$ in diameter, $1.5 \mu \mathrm{m}$ in maximum length, without intracellular membranes (Fig. 5B). This type often displayed a clear, microfibrillar central area with a dense core (Fig. 2A, C) (3) Cells approximately $1 \mu \mathrm{m}$ in diameter, without stacked membranes and with a large, clear central area, were very rarely observed in localised zones of the mesohyl (Fig. 2A).

\section{Enzymes}

Significant methanol dehydrogenase activity was found in each of the 3 tissue samples analyzed 10.35 , 0.48 , and 0.56 international units $\mathrm{g}^{-1} \mathrm{~min}^{-1}$ ). These levels are comparable to those found in the gill tissue of mussels harboring methanotrophic bacteria (Cavanaugh 1993, Fisher 1993). This is strong evidence for the presence of abundant methanotrophic symbionts in this sponge (Nelson \& Fisher 1995). Low activities of RuBP carboxylase were detected in the samples $(0.001$ international units $\mathrm{g}^{-1} \mathrm{~min}^{-1}$ ), which could be due to either Type $\mathrm{x}$ methanotrophs, low activity in chemoautotrophic symbionts, or surface bacteria. Neither ATP sulfurylase nor APS reductase activities were detectable in any of the 3 tissue samples (limits of detection for these assays were between 0.1 and 0.2 international units $\mathrm{g}^{-1} \mathrm{~min}^{-1}$ ).

\section{Stable isotopes}

The tissue $\delta{ }^{13} \mathrm{C}$ values were very similar in the 3 sponge samples analyzed $(-48.4,-48.5,-48.8 \%)$. These 


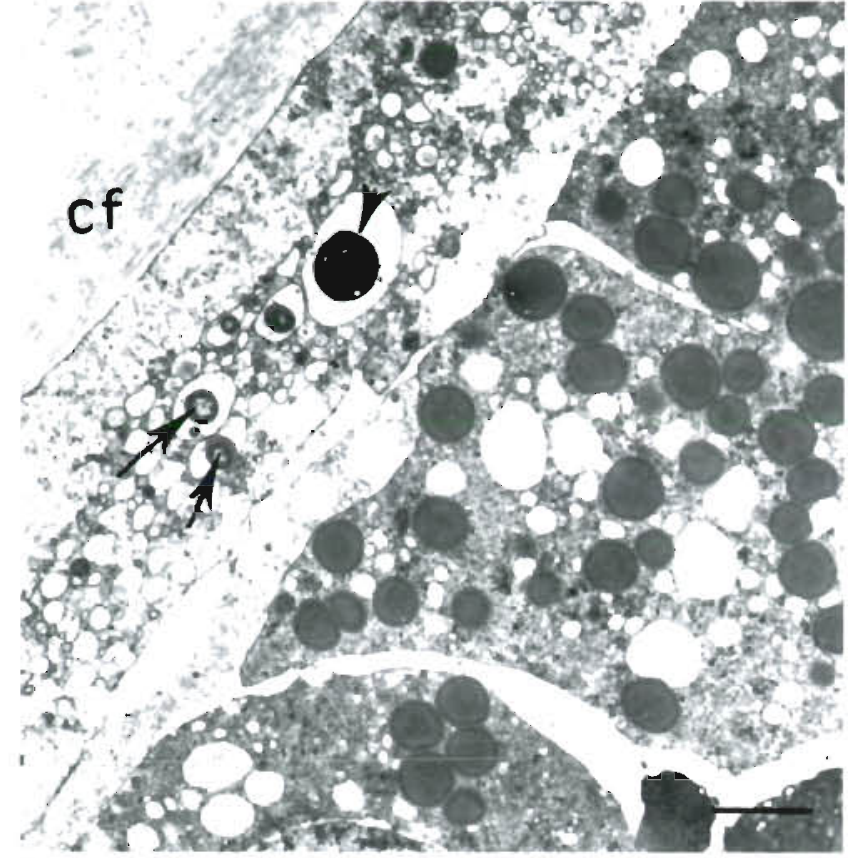

Fig. 4. Microsymbionts in the embryo of Cladorhiza sp. The embryo is enveloped by a dense layer of collagen fibrils (CF). The surface cells contain healthy rod-shaped bacteria (arrows) and Type I methanotrophs (arrowhead) occurring singly in membrane-bound vacuoles. The embryo internal cells, with numerous yolk inclusions, do not contain symbionts. Scale bar $=1.6 \mu \mathrm{m}$

values are consistent with incorporation of methane into the sponge, as a methane hydrate collected from the same site was $-58.1 \pm 0.2 \%$ (Henry et al. in press), and methane from the pore fluid on the volcanoes was -60 to $-65 \%$ (Martin et al. in press). Tissue $\delta^{15} \mathrm{~N}$ values $(+2.0$, 2.4 , and $2.9 \%$ ) were relatively light and lower than what has been reported for normal deep-sea fauna, but well within the range reported for other vent and seep fauna (Fisher et al. 1994, Van Dover \& Fry 1994).

\section{DISCUSSION}

The ultrastructure of the dominant morphological type of symbiont and the level of methanol dehydrogenase activity in the sponge tissues suggest that the sponge symbionts are methanotrophic bacteria. The hypothesis that the sponge derives some of its nutrition from its methanotrophic symbionts is supported by the very negative $\delta^{13} \mathrm{C}$ values and the low $\delta^{15} \mathrm{~N}$ values which reflect significant input of methane and organic nitrogen of local origin. The levels of methanol dehydrogenase in the sponge tissue are comparable to those found in mussels which rely heavily on their methanotrophic symbionts for nutritional carbon (Fisher \& Childress 1992, Fisher 1993), indicating that sufficient symbionts are present to contribute significantly to the sponges' nutrition. Ultrastructural observations indicate that the nutritional relationship between host and symbionts is based on phagocytosis. A similar mechanism has been suggested for a variety of other chemoautotrophic and methanotrophic symbioses (Fiala-Médioni 1988, Fiala-Médioni et al. 1989, Fiala-Médioni \& Felbeck 1990, Fisher \& Childress 1992, Nelson \& Fisher 1995). As discussed below, the peculiarity here is that the symbionts are normally extracellular, with nutrient transfer between host and symbionts occurring through phagocytosis and intracellular digestion of ageing bacterial cells within most of the sponge cell types.

The distribution and habitus of the sponges also provide evidence for nutritional reliance of the sponge on methane. Deep-sea cladorhizids are normally sparsely distributed and occur in low densities as discrete individuals, either anchored by rhizoids in muddy sediment or attached to small debris. The population density of representatives of the genera Cladorhiza and Asbestopluma has been estimated from photographs and video images to be 4 to 5 individuals $\mathrm{ha}^{-1}$ in the abyssal zone near Clarion and Clipperton in the tropical Pacific (Tilot 1992). This contrasts with the abundance and size of Cladorhiza sp. observed in the present study around the mud volcanoes. The sponge occurred in dense clumps, up to $2 \mathrm{~m}$ in diameter and $40 \mathrm{~cm}$ high, of several hundred individuals (Fig. 1) in the central depression, or eye, of the diatreme Atalante. The central depression itself was filled with warm mud and was the site of the most active methane expulsion (Le Pichon et al. 1990, Olu 1996, Olu et al. in press). The sponges were most abundant at the immediate periphery 10 to $100 \mathrm{~m}$, 'léopard facies', Le Pichon et al. 1990) of the eye, mostly on the east side. Smaller bushes $(0.2$ to $0.5 \mathrm{~m}$ in diameter) were abundant between $100 \mathrm{~m}$ and $250 \mathrm{~m}$ from the edge of the eye ('yellow facies'). No sponges were seen on the diatreme Cyclope, in which the estimated methane flux $\left(60 \mathrm{~kg} \mathrm{~d}^{-1}\right)$ is less than $1 \%$ of that of the diatreme Atalante $\left(8000 \mathrm{~kg} \mathrm{~d}^{-1}\right.$ ) (Olu et al. in press). The unusually high density of very large aggregates of Cladorhiza sp. at the mud volcano site, with size and abundance of the sponge bushes clearly correlated with the methane flow, also supports the thesis that the sponge derives substantial benefits from the methane source. Although the sponge, which is apparently devoid of the normal cladorhizid rhizoid system for growth on mud, may also benefit from the presence of a carbonate crust providing a substrate, it is unlikely that the availability of a hard substrate alone would result in such remarkable aggregations.

The sponge morphology, erect with branching processes bearing a thick cover of hook-like microsclere 

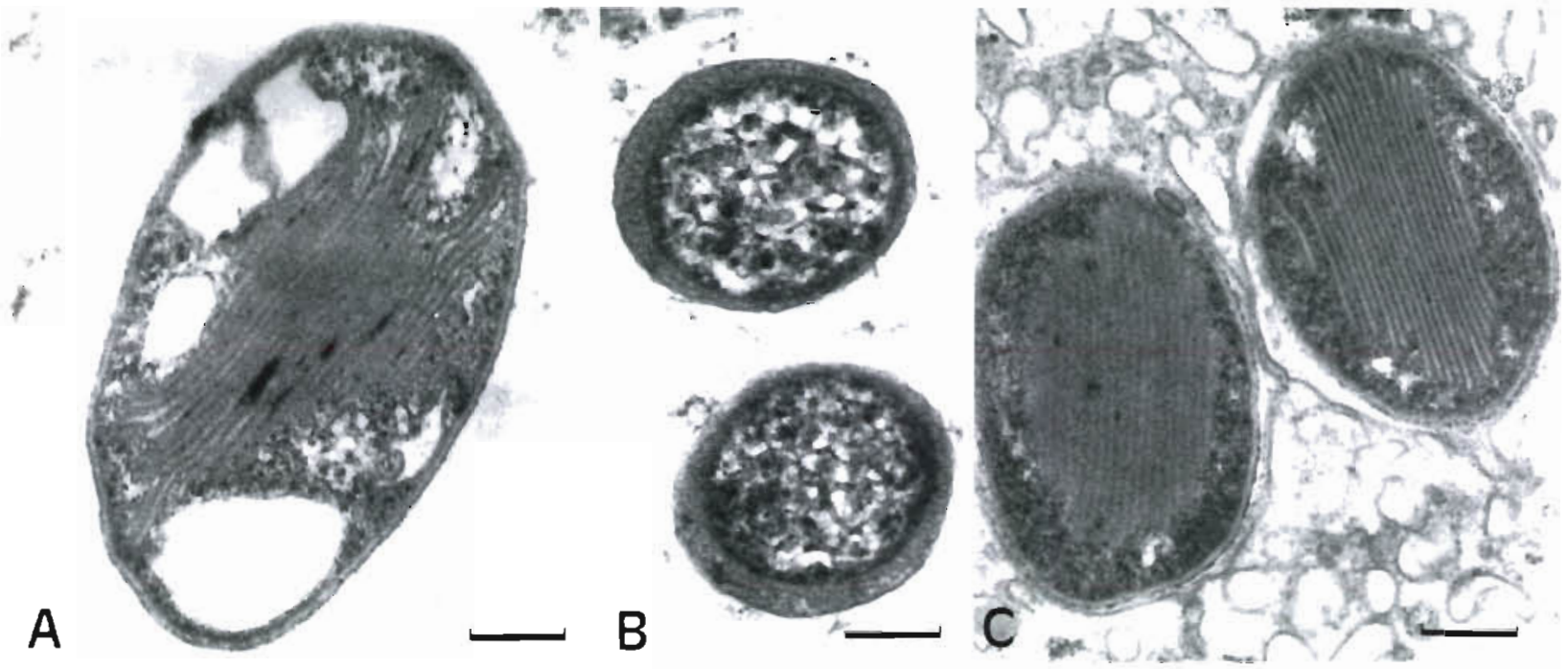

Fig. 5. Structure of the microsymbionts of Cladorhiza sp. (A) Extracellular bacteria with stacked membranes (Type I methanotroph). Scale bar $=0.2 \mu \mathrm{m}$. (B) Small coccoid or rod-shaped bacteria in extracellular position. Scale bar $=0.2 \mu \mathrm{m}$. (C) Intracellular Type I methanotroph, occurring singly in vacuoles. Scale bar $=0.25 \mu \mathrm{m}$

spicules, suggests that the sponge may also feed on small swimming prey, as do other cladorhizids (Vacelet \& Boury-Esnault 1995). This was supported by the presence of debris from small crustaceans, 0.5 to $1 \mathrm{~mm}$ in length, trapped on the appendages of the sponges, and the number of 'associate' crustaceans and polychaetes collected with the sponge (Bellan-Santini 1990, Ségonzac pers. comm.). Although originally considered as associated fauna (Bellan-Santini 1990), the crustaceans and polychaetes were more probably prey in the process of capture or digestion. Although the relative importance of carnivory and methanotrophy cannot be evaluated from these observations, it appears unlikely that such large aggregations of carnivorous sponges could survive in the deep sea in the absence of added nutritional input. Feeding on free-living methanotrophic bacteria is unlikely, as cladorhizid sponges, devoid of an aquiferous system, are not filter feeders (Vacelet \& Boury-Esnault 1995).

Two morphological types of symbionts dominate the association, and the evidence indicates that at least one of these is methanotrophic. The current data are insufficient to draw conclusions with respect to the second dominant morphological type of symbiont, the rodlike bacteria. Dual symbioses with both chemoautotrophic sulfur bacteria and methanotrophic bacteria have been recognised in mytilid molluscan hosts (Fisher et al. 1993, Distel et al. 1995) and this is a possibility in this association. However, the lack of detectable ATP sulfurylase or APS reductase activity, coupled with the very low levels of RUBISCO activity, suggest that if this is the case then the sulfur-oxidizing bacteria were relatively minor components of the sponge tissue. It is also possible that the low level of RUBISCO activity detected was due to either Type $x$ methanotrophs or contaminating chemoautotrophic bacteria associated with the surface of the sponge tissue samples.

The symbionts are present in several different locations, both extra- and intracellularly, in the sponge tissue. Healthy, intact symbionts were found extracellularly in the sponge mesohyl. They were most often in the process of degradation when intracellular, with the notable exception of surface cells of the embryo. This is similar to what is observed in many other sponges symbiotic with heterotrophic bacteria (Vacelet \& Donadey 1977. Wilkinson 1987). In these other sponges, 1, 2, or a large number of morphological types of bacteria are present extracellularly within the sponge tissue, and are phagocytized and digested by specific sponge cell types. This is also observed in most phototrophic associations between shallow-water sponges and unicellular cyanobacteria. The peculiarity in this association with methanotrophs is the abundance of bacteria in the process of degradation within all the sponge cell types.

The association is different from those of most other invertebrates with methanotrophic or chemoautotrophic sulfur-oxidizing symbionts, in which the symbionts are generally housed within cells, where they can both develop and occur in phagolysosomes (FialaMédioni \& Métivier 1986, deBurgh et al. 1989, FialaMédioni \& Felbeck 1990). However, similar complex situations in which healthy extracellular chemoautotrophic bacteria are phagocytized and digested by epi- 
dermal or gill cells are known in gutless oligochaetes (Giere \& Langheld 1987) and in thyasirid molluscs (Southward 1986)

The presence of intact symbionts in cells at the surface of embryos suggests a mechanism for direct transmission of the symbionts between generations. This is again reminiscent of littoral 'bacteriosponges', where bacteria are transmitted between generations in oocytes (Lévi \& Lévi 1976) or in follicle cells shed with the oocytes (Gallissian \& Vacelet 1976). A similar mechanism of direct symbiont transmission has been suggested for clams with chemoautotrophic symbionts (Endow \& Ohta 1990, Cary \& Giovannoni 1993).

Two other apparently similar associations between sponges and methanotrophic bacteria have been reported in preliminary papers: a Hymedesmia sp. encrusting on vestimentiferan tube worms from hydrocarbon seep communities in the Gulf of Mexico, $600 \mathrm{~m}$ deep (Harrison et al. 1994), and a fresh-water sponge, Baikalospongia intermedia, from thermal vents of the deep lake Baikal (Efremova et a]. 1995). The fact that such symbioses with methanotrophic bacteria exist in sponges widely differing in habitat, morphology, anatomy and feeding strategy (the marine Hymedesmia and fresh-water Baikalospongia being sponges with a 'normal' aquiferous system and filter-feeding habit, whereas Cladorhiza is a stalked, carnivorous sponge without an aquiferous system) could mean that methanotrophic associations are frequent in sponges from methane-rich environments, although they have not been previously recognized.

Acknowledgements. We are especially grateful to Prof. X. Le Pichon for providing the opportunity to dive and collect the sponges, as well as to the scientific crew of the 'Baresnaut' and 'Manon' cruises (1987 and 1992). We also thank the 'Nautile' and 'Atalante' crews for their efficient cooperation. The tissue stable carbon and nıtrogen analyses were conducted by J. Boulegue and A. Mariottr. We thank C. Bézac and M. Streams for technical assistance. This work was supported by INSU/CNRS, URA 117, URA 41, OTAN CRG 9310552 and NSF EAR9158113

\section{LITERATURE CITED}

Anthony C, Zathman LJ (1965) The microbial oxidation of methanol: the alcohol dehydrogenase of Pseudomonas sp. M27. Biochem J 96:808-812

Bellan-Santini D (1990) Nouvelles espèces d'Orchomene S.L. (Crustacea-Amphipoda) des fonds abyssaux. Affinités avec les autres Orchomene profonds. Beaufortia 41:15-24

Borojevic R. Lévi P (1967) Le basopinacoderme de l'éponge Mycale contarenii (Martens). Technique d'étude des fibres extracellulaires basales. J Microscopie 6(6):857-862

Boury-Esnault N, De Vos L (1988) Caulophacus cyanae n.sp., une éponge hexactinellide des sources hydrothermales. Biogéographie du genre Caulophacus Schulze, 1887 Oceanol Acta 8:51-60
Cary SC, Giovannoni SJ (1993) Transovarial inheritance of endosymbiotic bacteria in clams inhabiting decp-sea hydrothermal vents and cold seeps. Proc Natl Acad Sca USA 90:5695-5699

Cavanaugh CM (1992) Methanotroph-invertebrate symbioses in the marine environment: ultrastructural, biochemical and molecular studies. In: Murrell JC, Kelly DP (eds) Microblal growth on C1 compounds. Intercept Scientific, Andover, p 315-328

Childress JJ, Fisher CR, Brooks JM, Kennicut II MC, Bidigare $R$, Anderson AE (1986) A methanotrophic marine molluscan (Bivalvia, Mytilidae) symbiosis: mussels fueled by gas. Science 233:1306-1308

Davies SL, Whittenbury R (1970) Fine structure of methane and other hydrocarbon utilizing bacteria. J Gen Microbiol 61:227-232

deBurgh ME, Juniper SK, Singla CL (1989) Bacterial symbiosis in Northeast Pacafıc Vestimentifera: a TEM study. Mar Biol 101:97-105

Distel DL, Lee HKW, Cavanaugh CM (1995) Intracellular coexistence of methano- and thioautotrophic bacteria in a hydrothermal vent mussel. Proc Natl Acad Sci USA 92: 9598-9602

Efremova SM, Fialkov VA, Kouzin VS (1995) Methanotrophic symbiotic bacteria are found in deepwater sponges. The Second Vereshchagin Baikal Conference. Irkutsk, Russia, October 5-10, 1995. Abstracts, p 62-63

Endow $\mathrm{K}$, Ohta $\mathrm{S}$ (1990) Occurrence of bacteria in the primary oocytes of vesicomyid clam Calyptogena magnifica. Mar Ecol Prog Ser 64:309-311

Felbeck $H$ (1981) Chemoautotrophic potential of the hydrothermal vent tube worm, Riftia pachyptila Jones (Vestimentifera). Science 213:336-338

Fiala-Medioni A (1988) Synthèse sur les adaptations structurales liées à la nutrition des mollusques bivalves des sources hydrothermales profondes. Oceanol Acta 8: $173-179$

Fialcl-Médioni A, Felbeck H (1990) Autotrophic processes in invertebrate nutrition: bacterial symbiosis in bivalve molluscs. In: Kinne RKH, Kinne-Saffran E, Beyenbach KW (eds) Comparative physılogy, Vol 5. Karger, Basel, p 49-69

Fiala-Médioni A, Felbeck $H_{1}$ Childress JJ, Fisher CR, Vetter RD (1989) Lysosomic resorption of bacterial symbionts in deep-sea bivalves. In: Nardon P, Gianinnazi-Pearson $V$, Grenier AM, Margulis L, Smith DC (eds) Endocytobiology, Vol 4. Villeurbanne p 335-338

Fiala-Médioni A, Métivier C (1986) Ultrastructure of the gill of the hydrothermal. vent bivalve Calyptogena magnifica, with considerations on its nutrition. Mar Biol 90:215-222

Fisher CR (1993) Oxidation of methane by deep-sea mytiluds in the Gulf of Mexico. In: Oremland RS (ed) Biogeochemistry of global change: radiatively active trace gases. Chapman and Hall Inc. New York, p 606-618

Fisher CR, Brooks JM, Vodenichar JS, Zande JM, Childress JJ, Burke RA (1993) The co-occurrence of methanotrophic and chemoautotrophic sulfur-oxidizing bacterial symbionts in a deep-sea mussel. PSZN I: Mar Ecol 14:277-289

Fisher CR, Childress JJ (1992) Organic carbon transfer from methanotrophic symbionts to the host hydrocarbon-seep mussel. Symbiosis 12:221-235

Fisher CR, Childress JJ, Macko SA, Brooks JM (1994) Nutritional interactions in Galapagos Rift hydrothermal vent communities: inferences from stable carbon and nitrogen isotope analyses. Mar Ecol Prog Ser 103:45-55

Gallissian MF, Vacelet J (1976) Ultrastructure de quelques stades de l'ovogenèse de spongiaires du genre Verongia (Dictyoceratida). Ann Sci Nat Zool Biol Anim 18:381-404 
Giere O, Langheld C (1987) Structural organization, transfer and biological fate of endosymbiotic bacteria in gutless oligochaetes. Mar Biol 93:641-650

Grassle JF (1986) The ccology of deep sea hydrothermal vent communities. Adv Mar Biol 23:301-362

Harrison FW, Gardiner SL, Rützler K, Fisher CR \{1994\} On the occurrence of endosymbiotic bacteria in a new species of sponge from hydrocarbon seep communities in the Gulf of Mexico. Trans Am Microsc Soc 113:419-420

Henry P, Le Pichon X, Lallemand S, Foucher JP, Westbrook G, Hobart M (1990) Mud volcano field seaward of the Barbados accretionary complex: a deep-towed side scan sonar survey. J Geophys Res 95:8917-8929

Henry $\mathrm{P}$, Le Pichon X, Lallemand S, Lance S, Martin J, Foucher JP, Fiala-Médioni A, Rostek F. Guilhaumou N, Pranal V. Castrec M (1996) Fluid flow in and around volcano field seaward of the Barbados accretionary wedge: results trom Manon cruise. J Geophys Res 101(B9): 20297-20323

Higgins IJ, Best DJ, Hammond RC, Scott D (1981) Methaneoxidızing microorganisms. Microbiol Rev 45:556-590

Le Pichon X, Foucher JP, Boulègue J, Henry P, Lallemand S, Benedetti M. Avedik. F, Mariotti A. (1990) Mud volcano field seaward of the Barbados accretionary complex: a submersible survey. J Geophys Res 95:8931-8943

Lévi C, Lévi P (1976) Embryogenese de Chondrosia reniformis ( $N a r d o)$, démosponge ovipare, et transmission des bactéries symbiotiques. Ann Sci Nat Zool Biol Anim 18: $367-380$

Lundbeck W (1905) Porifera. Pars II: Desmacidonidae (pars). Danish Ingolt Expedition 6(2):1-219

Martin JB, Kastner M, Le Pichon X, Lallemand S, Henry P (in press) Chemical and isotopic evidence for ongins of fluids in and around Barbados mud volcanoes. J Geophys Res

Nelson DC, Fisher CR (1995) Chemoautotrophic and methanotrophic endosymbiotic bacteria at deep-sea vents and seeps. In: Karl DM (ed) Microbiology of deep-sea hydrothermal vent habitats. CRC Press, Boca Raton, $p$ $125-168$

Olu K (1996) Structure et répartition spatiale des communautés benthiques associées aux sources de fluides froids sur les marges continentales: cas de zones de subduction Doctorat ès Sciences Thesis, Université Paris 6

This article was submitted to the editor
Olu K, Lance S, Sibuet M, Fiala-Médioni A, Dinet A ( $1 n$ press) Spatial distribution of cold seep communities as indicators of fluid expulsion patterns through mud volCanoes on the Barbados accretionary prism. Deep Sea Res

Reiswig HM (1981) Partial carbon and energy budgets of the bacteriosponge Verongia fistularis (Porifera: Demospongrae) in Barbados. PSZN l: Mar Ecol 2:273-293

Sars GO (1872) On some remarkable forms of animal life from the great deeps off the Norwegian coast. I. Partly from posthumous manuscripts of the late professor Dr. Michael Sars. Brogger \& Christie, Christiana

Southward EC (1986) Gill symbionts in thyasirids and other bivalve molluscs. J Mar Biol Assoc UK 66:889-914

Tilot V (1992) La structure des assemblages mégabenthiques d'une province à nodules polymétalliques de l'Océan Pacifique tropical Est. Doctorat ès Sciences Thesis, Unıversité de Bretagne occidentale, Brest

Tunnicliffe $V$ (1991) The biology of hydrothermal vents: ecology and evolution. Oceanogi Mar Biol Annu Rev 29 $319-407$

Vacelet J (1975) Étude en microscopie électronique de l'association entre bactéries et spongiaires du genre Verongia (Dictyoceratida). J Microsc Brol Cell 23:271-288

Vacelet J, Boury-Esnault N (1995) Carnivorous sponges Nature 373:333-335

Vacelet J, Boury-Esnault N, Fiala-Médioni A, Fisher CR (1995) A methanotrophic carnivorous sponge. Nature 377: 296

Vacelet J, Donadey C (1977) Electron microscope study of the association between some sponges and bactera. J Exp Mar Biol Ecol 30:301-314

Van Dover CL, Fry B (1994) Microorganisms as food resources at deep-sea hydrothermal vents. Limnol Oceanogr 39: $51-57$

Wilkınson C (1987) Significance of microbial symbionts in sponge evolution and ecology. Symbiosis 4:135-146

Wilkinson C (1992) Symbiotic interactions between marine sponges and algae. In: Reisser $W$ (ed) Algae and symbioses: plants, animals, fungi and viruses, interactions explored. Biopress, Bristol, p 112-151

Wishnick M, Lane MD (1971) Ribulose diphosphate carboxylase from spinach leaves. Methods Enzymol 23:571

Manuscript first received: July 16, 1996

Revised version accepted: October 21, 1996 